\title{
Spatial and Temporal Analysis of El Niño Impact on Land and Forest Fire in Kalimantan and Sumatra
}

\author{
Sri Nurdiati ${ }^{1}$, Ardhasena Sopaheluwakann ${ }^{2}$, Pandu Septiawan ${ }^{1}$ \\ ${ }^{1}$ Department of Mathematics, FMIPA Building, IPB Dramaga Campus, Bogor, Indonesia 16680 \\ ${ }^{2}$ Meteorological, Climatological, and Geophysical Agency, Kemayoran, Jakarta Pusat, DKI Jakarta, Indonesia 10610
}

\section{ARTICLE INFO}

\section{Received}

23 July 2020

\section{Revised}

29 November 2020

\section{Accepted for Publication}

15 December 2020

\section{Published}

25 Januari 2021

\section{doi: 10.29244/j.agromet.35.1.1-10}

\section{Correspondence:}

Sri Nurdiati

Department of Mathematics,

FMIPA Building, IPB Dramaga Campus, Bogor, Indonesia 16680

Email: nurdiati@apps.ipb.ac.id
This is an open-access article distributed under the CC BY License. (c) 2020 The Authors. Agromet.

\begin{abstract}
A B S T R A C T
Land and forest fires in Kalimantan and Sumatra, Indonesia occurred annually at different magnitude and duration. Climate and sea interaction, like El Niño, influences the severity of dry seasons preceding the fires. However, research on the influence of El Niño intensity to fire regime in Kalimantan and Sumatra is limited. Therefore, this study aims to analyze the spatial and temporal patterns of the effects of El Niño intensity on land and forest fires in fire-prone provinces in Indonesia. Here, we applied the empirical orthogonal function analysis based on singular value decomposition to determine the dominant patterns of hotspots and rainfall data that evolve spatially and temporally. For analysis, the study required the following data: fire hotspots, dry-spell, and rainfall for period 2001-2019. This study revealed that El Niño intensity had a different impacts for each province. Generally, El Niño will influence the severity of forest fire events in Indonesia. However, we found that the impact of El Niño intensity varied for Kalimantan, South Sumatra, and Riau Province. Kalimantan was the most sensitive province to the El Niño event. The duration and number of hotspots in Kalimantan increased significantly even in moderate El Niño event. This was different for South Sumatra, where the duration and number of hotspots only increased significantly when a strong El Niño event occurred.
\end{abstract}

KEYWORDS

drought, empirical orthogonal function, fire regime, hotspots, singular value decomposition

\section{INTRODUCTION}

Land and forest fires in Indonesia occur annually especially in dry season. The fires happen with different scale and duration. Many factors influence fire occurrence in Indonesia associated with climate phenomenon (Albar et al., 2018; Ma et al., 2020). One of the regional phenomena that affect climate in Indonesia is El Niño-Southern Oscillation (ENSO). ENSO relates to the pattern of sea water temperature in the central and eastern tropical Pacific Ocean (Cai et al., 2018; Capotondi et al., 2020). Two extreme phases of ENSO cycle are El Niño and La Niña. In Indonesia, El Niño associated with prolong dry season (Hidayati and Chrisendo, 2010; Supari et al., 2018; Wahab et al., 2009), whereas La Niña relate to high rainfall (Hidayat et al., 2018). Prolonged dry season triggered by El Niño has caused severe impacts on agriculture (Mulyaqin, 2020; Nóia Júnior and Sentelhas, 2019; Surmaini et al., 2018), water resource (Taufik, 2010), and environment (Chapman et al., 2020). The most pronounce impacts is land and forest fires that causing severe peat land degradation (Sze and Lee, 2019) and health related issues (Demissie and Mengisitie, 2017) such as in 1997 and 2015 fires.

In addition to ENSO, rainfall in Indonesia is influenced by dynamics of sea surface temperature in Indian Ocean called as Indian Ocean Dipole (IOD). When positive IOD coincides with El Niño event, rainfall in Indonesia substantially decreases comparing to that of the positive IOD event only or El Niño event. Otherwise, when negative IOD and La Niña occur, Indonesia's rainfall increases more significantly than a single negative IOD or 
La Niña event (Nur'utami and Hidayat, 2016). This phenomenon occurred in 1997, when a strong El Niño coincided a strong positive IOD had caused a severely declined rainfall in most Indonesia (Avia and Sofiati, 2018; Fanin and Werf, 2017). Similar events were recorded in 2006 and 2007.

The El Niño event worsen impacts of dry season such as triggering huge fire in the 2015 (Stiegler et al., 2019).The total loss that resulting from fires in period 2015-2019 is the total burned land and forest of more than 5.3 million $\mathrm{km}^{2}(\mathrm{KLHK}, 2020)$. Based on these disadvantages, the research about El Niño impact on forest fire in Indonesia is needed. In the last 20 years, there are several areas in Indonesia that vulnerable to forest fire, namely: Kalimantan, South Sumatra, and Riau (Albar et al., 2016; Septiawan et al., 2019). This research aims to characterize the compounding impacts of El Niño strength and dry-spell on land and forest fires spatially and temporally. By characterizing their impacts, we may identify the pattern of fire regime based on El Niño strength in the most fire prone regions in Indonesia namely Kalimantan, South Sumatra, and Riau. Our approach proposes to analyze the compounding impact of El Niño strength and dryspell. The outputs of the research will improve understanding of fires event in the regions. To study a fire regime, several characteristics of fire are applied including the area burned, carbon emissions, and hotspots. Here we only depend on the number of hotspots as indicator of land and forest fire.

\section{RESEARCH METHODS}

\section{Data}

This study used the number of hotspots, dryspell, and rainfall for the period 2001-2019. The study area was in three provinces namely Kalimantan $\left(7^{\circ} \mathrm{N}\right.$ $\left.4.5^{\circ} \mathrm{S}, 108^{\circ} \mathrm{E}-119^{\circ} \mathrm{E}\right)$, South Sumatra $\left(1.5^{\circ} \mathrm{S}-6^{\circ} \mathrm{S}, 100^{\circ} \mathrm{E}\right.$ - $\left.107^{\circ} \mathrm{E}\right)$, and Riau $\left(6^{\circ} \mathrm{N}-1.5^{\circ} \mathrm{S}, 95^{\circ} \mathrm{E}-104^{\circ} \mathrm{E}\right)$. The hotspot data was obtained from the National Institute of Aeronautics and Space of Indonesia (LAPAN) that was derived from the Moderate Resolution Imaging Spectroradiometer (MODIS) sensors of the Terra and Aqua Satellites with spatial resolution of $0.25^{\circ} \times 0.25^{\circ}$. We only used the hotspot data, which has a confidence level $>80 \%$ according to standard data of forest fire indicator as suggested by Ardiansyah et al. (2017).

The dry-spell data used was converted rainfall data, which was based on a satellite-derived product of The Space-based Weather and Climate Extremes Monitoring Demonstration Project (SEMDP) in East Asia and western Pacific. We employed daily rainfall based on Climate Prediction Center Morphing Technique (CMORPH) to obtain rainfall data on monthly basis. The monthly data were used for Standardize Precipitation
Index (SPI) calculation. The CMORPH data used in this study has been calibrated with the observed data based on the TRMM Multi-satellite Precipitation Analysis (TMPA 3B42) called as CMORPH satellite-gauge merged product (CMORPH BLD).

Previous researches suggested that the use of CMORPH BLD will improve the performance of hydrological model (Sun et al., 2016), and resulted a consistent output comparing with the observed rainfall when it used for SPI analysis (Lu et al., 2018). Therefore, the use of satellite rainfall data may produce a reliable estimate of drought event. Also, CMORPH BLD was outperformed than that of other CMORPH products when it applied to humid climate (Lu et al., 2018).

We applied threshold of $1 \mathrm{~mm}^{\text {day }}{ }^{-1}$ to convert the rainfall data to dry-spell. If the daily rainfall is less than $1 \mathrm{~mm}$, the respective day will be count as dry-spell. Then we only focused locations where there were fire activities based on hotspot data in Kalimantan, South Sumatra, and Riau. For ENSO we used data Niño 3.4, which is available online (https://ggweather.com/). Other regional sea-atmospheric interaction from Indian Ocean (http://www.bom.gov.au/climate/iod/) also was used to see the influence of regional phenomena on drought related fire events in three provinces. All data analysis was performed in Matlab r2017a. Figure 1 showed the Niño 3.4 index and IOD index.

\section{Empirical orthogonal function method based on singular value decomposition}

Satellite rainfall data from CMORPH is typically matrix data, which has large dimensions, therefore, an appropriate method is needed to analyze the data. One approach that often used to reduce the dimensions of matrix data is the Empirical Orthogonal Function (EOF) method based on Singular Value Decomposition (SVD). EOF method is used to determine the dominant patterns of data that evolve spatially and temporally. Output from EOF method is a linear combination related to spatial and temporal dimension. With EOF, spatial and temporal interaction were minimized. The EOF method based on SVD is so powerful than other correlation method that commonly used in climate research (Zhang et al., 2018).

Analytically, SVD is a matrix decomposition using a singular value as the main factor. Suppose that the matrix $\boldsymbol{A} \in \boldsymbol{R}_{\mathrm{m} \times n}$ with rank $r_{\text {, there is an orthogonal }}$ matrix $\boldsymbol{U}_{m} \times_{m}, \boldsymbol{V}_{n} \times_{n}$ and a diagonal matrix $D_{r} \times_{r}=\operatorname{diag}$ $\left(\sigma_{1}, \sigma_{2}, \ldots, \sigma_{r}\right)$, which is shown in Equation 1 :

$$
\boldsymbol{A}=U\left[\begin{array}{ll}
D & 0 \\
0 & 0
\end{array}\right]_{m \times n} V^{\mathrm{T}}
$$

where $\sigma_{1} \geq \sigma_{2} \geq \cdots \geq \sigma_{r}>0, \sigma_{i}$ is singular value from matrix $A$ and $r$ is number of singular values that obtained from the decomposition. 

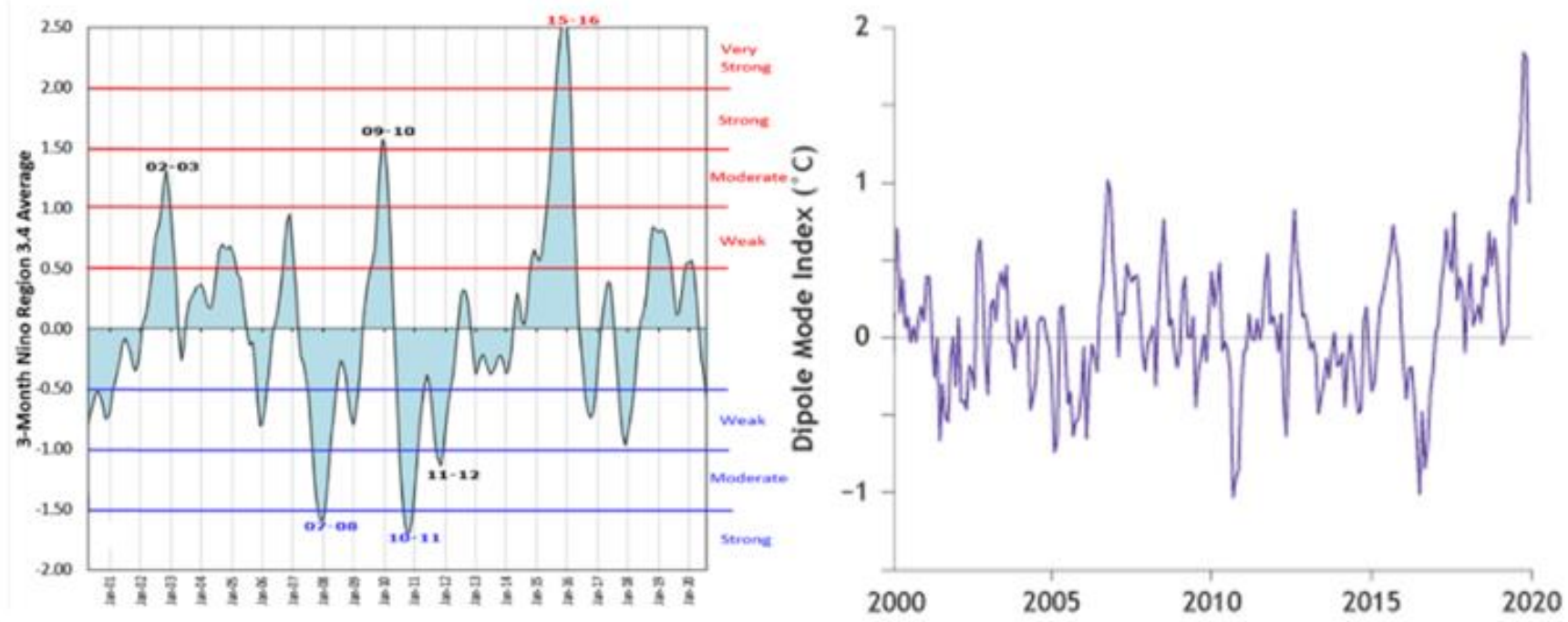

Figure 1. Time series of regional sea-atmospheric interaction: (a) Niño 3.4 index and (b) IOD index for period 2001-2009.

When $r<p=\min \{m, n\}$, $A$ have $p-r$ in addition to the singular zero value. Factorization in Equation 1 is the SVD of the matrix A. The columns in $\boldsymbol{U}$ and $\boldsymbol{V}$ represent left singular vector and right singular vector of $\boldsymbol{A}_{\text {, }}$ respectively (Sun et al., 2018).

For this research, hotspot data will be represented as $\boldsymbol{A}$ and dry-spell data will be represented as $\boldsymbol{B}$. For data matrix $\boldsymbol{A}$ and $\boldsymbol{B}$ that have same temporal range, both are processed by reducing the data with the average of each variable. Therefore, the median of each variable from matrix $\boldsymbol{A}$ and $\boldsymbol{B}$ is zero. Then a crosscorrective matrix will be formed (Equation 2).

$$
\boldsymbol{C}=\boldsymbol{A}^{\top} \boldsymbol{B}
$$

Then, SVD is used to reduce the cross-corrective matrix $\boldsymbol{C}$ to be $\boldsymbol{U}, \boldsymbol{L}$, and $\boldsymbol{V}$ matrix (Equation 3). SVD method based on cross-corrective matrix will produce better correlation than other SVD analysis. The decomposed matrix based on SVD is the result of multiplication from both matrix data.

$$
\boldsymbol{C}=\boldsymbol{U} \boldsymbol{L} \boldsymbol{V}^{\top}
$$

A singular vector $\boldsymbol{A}$ is columns in $\boldsymbol{U}$, whereas singular vector $\boldsymbol{B}$ is columns in $\boldsymbol{V}$. Each pair of singular vectors is a mode of co-variability between $\boldsymbol{A}$ and $\boldsymbol{B}$ data. Therefore, each column in $\boldsymbol{U}$ and $\boldsymbol{V}$ matrix is spatial pattern of each data. Then, to describe how each mode variability is oscillated spatially and temporally, a new term called as an expansion coefficient is introduced. The expansion coefficient for data $\boldsymbol{A}$ is calculated by multiplication the data $\boldsymbol{A}$ with its singular vector, $\boldsymbol{U}$, therefore $\boldsymbol{F}=\boldsymbol{A} \boldsymbol{U}$. Also, the expansion coefficient for data $\boldsymbol{B}$ is calculated by multiplication the data $\boldsymbol{B}$ with its singular vector, $\boldsymbol{V}$ therefore $\boldsymbol{G}=\boldsymbol{B} \boldsymbol{V}$. To choose the mode for analysis, we need to calculate the squared covariance fraction (SCF). We calculated SCF for each mode data as shown in Equation 4.

$$
S C F_{i}=l_{i}^{2} / \sum l_{i}^{2}
$$

where $l_{i}^{2}$ is a square of singular value and $\sum l_{i}^{2}$ is a total square of singular value. Mode with highest SCF value will be used to subsequent analysis spatially and temporally (Björnsson and Venegas, 1997).

\section{Identification Strength of El Niño Phenomenon}

El Niño index is derived from the average sea surface temperature anomaly in the Niño 3.4 region $\left(170^{\circ}-120^{\circ} \mathrm{BB}, 5^{\circ} \mathrm{LU}-5^{\circ} \mathrm{LS}\right)$. There are five categories of El Niño based on its strength, namely year (i) normal ($0.5-0.5$ ), (ii) weak (0.5-1), (iii) moderate (1-1.5), (iv) strong (1.5-2), and ( $v$ ) very strong (>2). Then we analyzed and discussed the result of the research based on this category. We identified ENSO condition for 2001-2019, which showed that all ENSO categories were reported. Period of 2001, 2003, 2013, and 2014 were categorized as a normal year. Weak El Niño category occurred in 2004, 2006, 2018, and 2019 periods. The category of moderate El Niño was happened in 2002 and 2009, while very strong El Niño in 2015.

\section{RESULTS AND DISCUSSIONS}

The results showed that the output of mode based on EOF method gave various squared covariance fraction (SCF) values. Based on analysis, the mode 1 had the highest SCF value i.e. $85 \%$. On other hand, others modes gave lower SCF value compared to the mode 1 . Therefore, the analysis only focused to the output of mode 1 , and other results from other modes were neglected. The result will be divided based on the location that have hotspots annually from 2001 until 2019, which is Kalimantan, South Sumatra and Riau (Septiawan et al., 2019). Since there are 2 drought 
seasons in Riau, the analysis will be split to $1^{\text {st }}$ drought of Riau and $2{ }^{\text {nd }} d$ of Riau.

\section{Kalimantan}

Kalimantan is one of the endemic locations that annually have many hotspots occurred in last 20 years, especially in the south part of Kalimantan. Moreover, when El Niño become stronger, the drought season in Kalimantan become longer. Therefore, it can lead to produce more hotspots than the normal condition. The temporal pattern of Kalimantan from variable of hotspots and dry-spell will be showed on Figure 2. As a note, the decomposition of those 2 variables done separately for every El Niño categories. Also, some year was removed from the analysis due to long rainy season caused of La Nina. For the spatial pattern, the spatial pattern that shows was only from the moderate season. The spatial pattern was almost similar for all analysis, the difference only occurred in the severity of the location due to different strength of El Niño phenomenon.

Figure 2 shows that the highest number of hotspots in 1 month occurred in 2019 with more than 12000 hotspots, but the highest number of hotspots in 1 drought season occurred in 2015 with more than 20,000 hotspots. For the normal year, the number of the hotspots was less than 5000 hotspots in 1 drought season. Moreover, 2001 and 2013 have much less hotspots than 2003 and 2012 event. This fact can be explained by looking the El Niño index in Figure 1. Although 2001 and 2013 were categories as normal year, the El Niño index was less than 0 (negative), which indicates that both years have more rain in each year compared to 2003 and 2012.

For weak El Niño event, the result was diverse from each year. The highest one was in 2019 event where there were more than 12,000 hotspots in 1 month. The second highest one was in 2006 event with more than 10,000 hotspots in 1 month. Both of those year was the year of positive IOD. When a El Niño and positive IOD are concurrently occurred, Indonesia is more significantly decreased than in the single El Niño event (Qalbi et al., 2017). Moreover, IOD occurred 2019 that reached the level of the strongest events occurred in 1994 and 1997 and caused disasters in countries around the Indian Ocean (Doi et al., 2020). For 2018, the lower hotspots was associated with government effort to prevent forest fires in order to succeed SEA GAMES 2018 in Palembang (Ruiz and Putraditama, 2019).

The result for moderate El Niño event in Kalimantan was similar for both years with around 10,000 hotspots in 1 drought season. If we exclude the 2006 and 2019 event from weak El Niño that has positive IOD, the number of hotspots that occurred in 1 drought season was twice as much as the weak El Niño years. The number of hotspots in 1 month in very strong El Niño event that occurred in 2015 didn't have much different compared to moderate El Niño. However, there was 2 month that have more than 10,000 hotspots in each month. Therefore, the number of total hotspots in 1 drought season nearly double the moderate El Niño year. The results obtained are similar to Yananto and Dewi (2016) study where the number of hotspots continues to increase from July to October in both regions. In November 2015, the number of hotspots had decreased drastically in line with the increase amount of rainfall (Yananto and Dewi 2016).

\section{South Sumatra}

Figure 3 shows that the highest number of hotspots in 1 month occurred in 2015, which is very strong
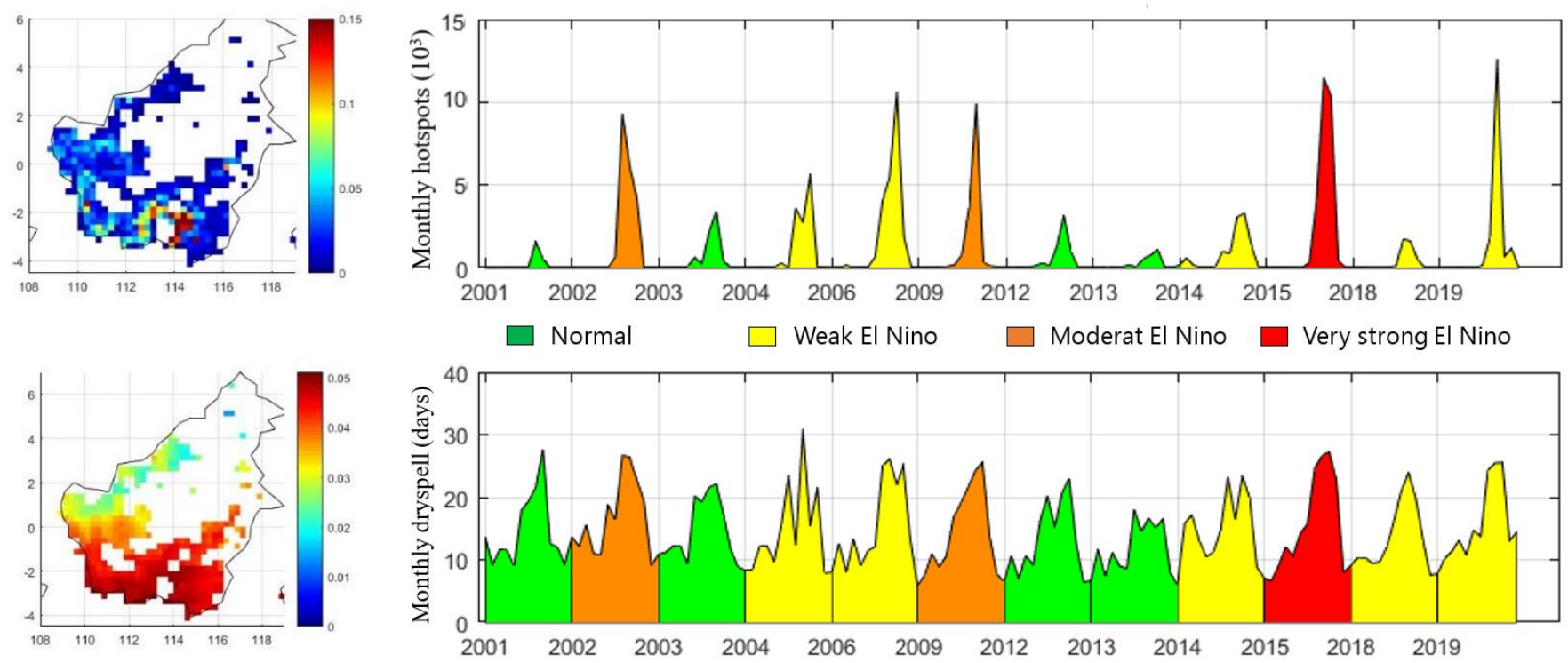

Figure 2. Spatial distribution of severity level and temporal pattern of hotspots (top) and spatial distribution of severity level and temporal pattern of dry-spell (bottom) in Kalimantan. 
El Niño years with more than 10,000 hotspots. A comparison with the $1997 \mathrm{El} \mathrm{Niño} \mathrm{event} \mathrm{shows} \mathrm{that} \mathrm{the}$ time evolution of the two events appears to be similar. However, the intensity of the impact was lower during the $2015 \mathrm{El}$ Niño as reflected in the fewer stations with dry and very dry conditions (Supari et al., 2018). Apart from the very strong El Niño years, the number of hotspots in South Sumatra was quite similar from each other, except years with positive IOD event. Even the moderate years, has less hotspots than 2004 and 2014 which is weak El Niño year. The number of hotspots in 1 month was less than 2,500 hotspots. As the previous analysis, hotspots in 2018 was also associated with government effort to prevent forest fires in order to succeed SEA GAMES 2018 event in Palembang (Ruiz and Putraditama, 2019).

This result indicates that El Niño phenomenon didn't have big impact for hotspots in South Sumatra, except for very strong El Niño. However, El Niño have quite impact to the dry-spell variable. El Niño constantly give longer dry season to south Sumatra. It can be seen by the width of drought season in each year. One of the reasons that reduced the impact of EI Niño in Sumatra is the length of drought season that slightly shorter than Kalimantan. Compared to Kalimantan, large number of hotspots only occurred in August and September, instead of August until October(Yulianti, 2013). The number of hotspots in October was decreased due to the increase of rainfall caused by monsoonal season in South Sumatra.

Positive IOD was defined when the mean of sea surface temperature (SST) in the West IOD region $\left(10^{\circ} \mathrm{N}\right.$ $-10^{\circ} \mathrm{S}, 50^{\circ} \mathrm{E}-70^{\circ} \mathrm{E}$ ) was warmer than the mean SST in the East IOD region $\left(0^{\circ}-10^{\circ} \mathrm{S}, 90^{\circ} \mathrm{E}-110^{\circ} \mathrm{E}\right.$ ) (Arora and Dash, 2019). Meanwhile, spatial pattern in Figure 3 shows that the area that used is at East IOD region. Therefore, IOD should have more impact in South
Sumatra than in Kalimantan. It can be seen by 2019 graphics that shows nearly twice as much as hotspots in 2006, although the number of hotspots not as much as in Kalimantan. It can be caused by the hotspot area of South Sumatra less than in Kalimantan. Another reason is the upcoming rainy monsoonal season that also reduced the El Niño impact in South Sumatra.

\section{$1^{\text {st }}$ Drought season of Riau}

The $1^{\text {st }}$ drought season of Riau was happened in January until March. The temporal plot in Figure 4 shows the monthly event that happened in January until April. Figure 5 shows that number of hotspots in 1 month that occurred in $1^{\text {st }}$ drought of Riau didn't exceed 2,000 hotspots, except in 2014. That result indicated that $\mathrm{El}$ Niño didn't have any big impact in $1^{\text {st }}$ drought season of Riau, so is the IOD. Positive IOD didn't have any clear impact in this analysis. This can be seen in Figure 4 where the number of hotspots in 2006 more than hotspots in 2019, even though 2019 IOD was stronger than 2006 IOD. Both of this result corresponds to the difference in time of occurrence between El Niño and IOD with the drought season. Meanwhile, the anomaly of hotspots in $1^{\text {st }}$ drought season in Riau happened in 2014 with more than 10,000 hotspots in 1 drought season.

Anomaly of drought season in 2014 was caused by the cold phenomenon and the contraction of the Intertropical Convergence Zone (ICTZ) to the south (McBride et al., 2015) which resulted in drought in the Riau region and large fires that year. This event was characterized by having 3 months of high dry-spell from February to March with more than 25 days of dryspell in each month. The southward contraction of the ITCZ is the extreme value in the recent time series. The mechanism causing the narrowing of the ITCZ is not known (McBride et al., 2015).
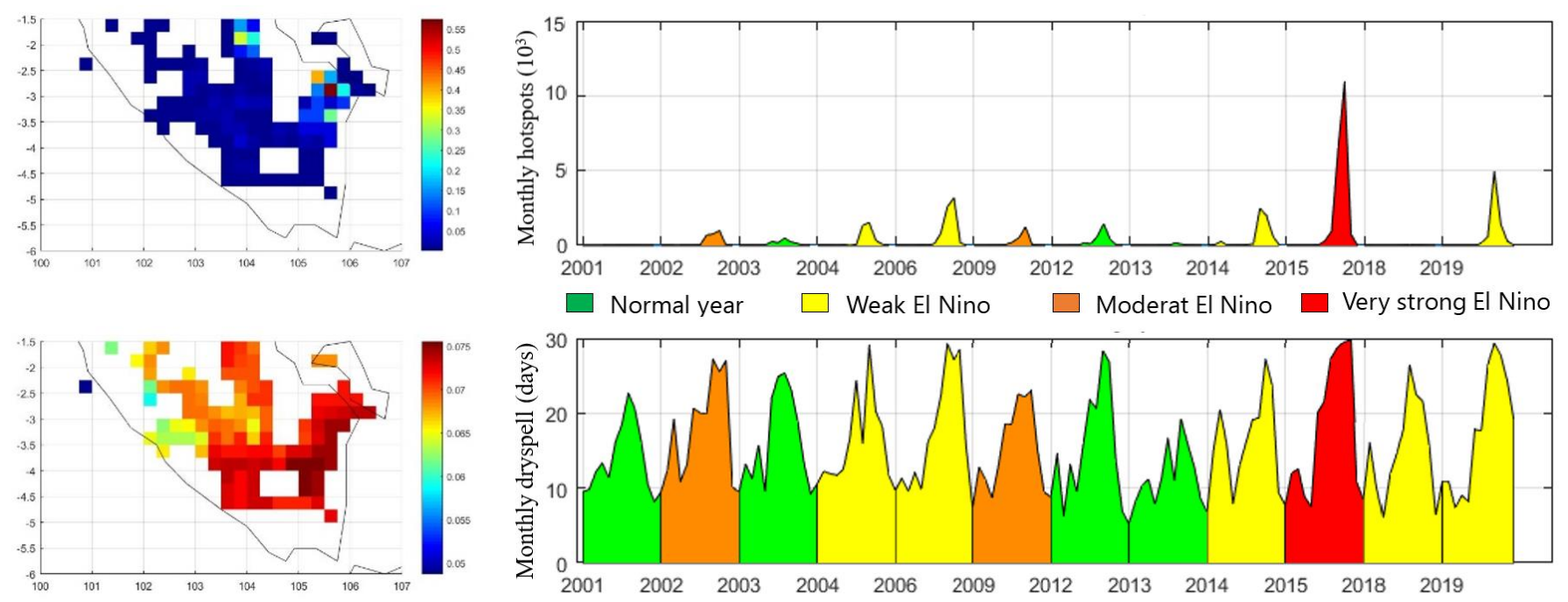

Figure 3. Spatial distribution of severity level and temporal pattern of hotspots (top) and spatial distribution of severity level and temporal pattern of dry-spell (bottom) in South Sumatra during normal year. 

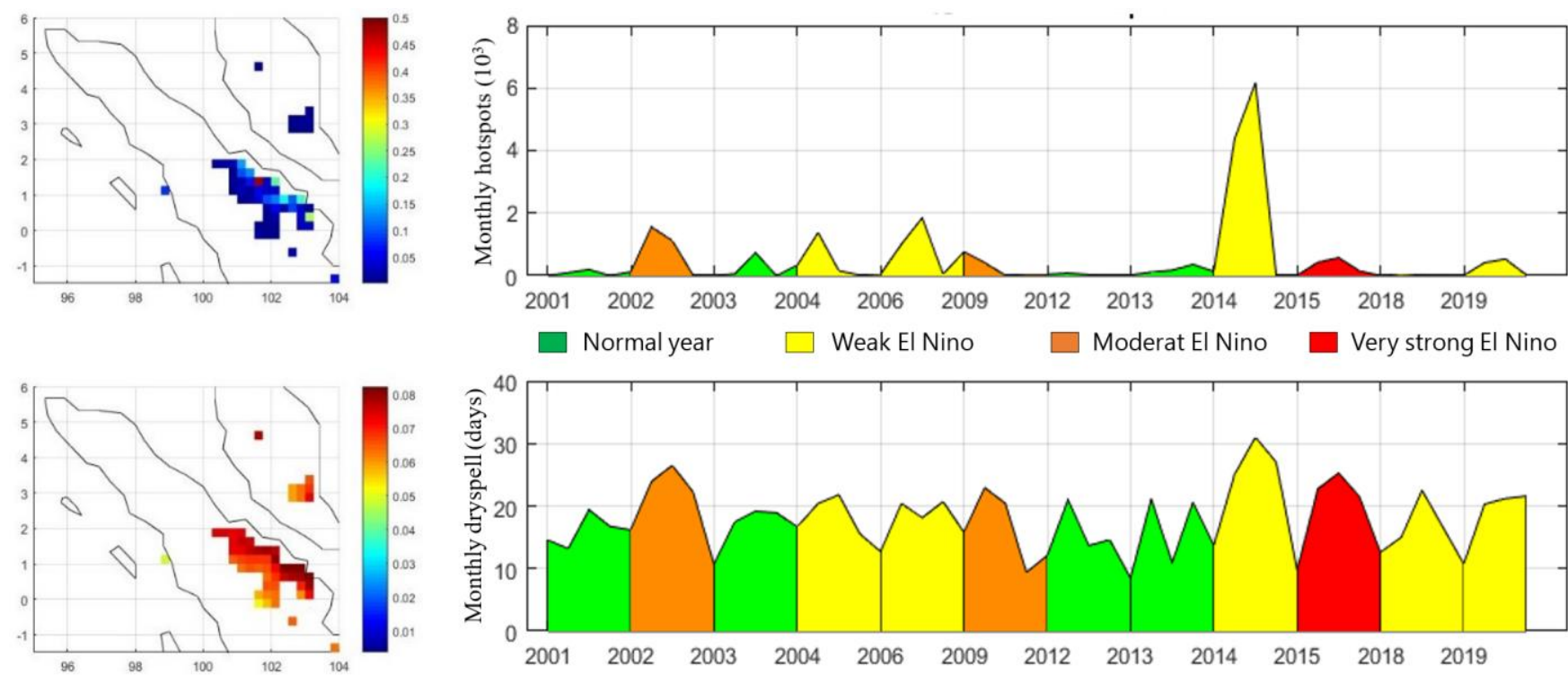

Figure 4. Spatial distribution of severity level and temporal pattern of hotspots (top) and spatial distribution of severity level and temporal pattern of dry-spell (bottom) in the first drought season in Riau.

The Madden-Julian Oscillation (MJO) also plays a role in the dry season from January to March 2014. MJO is the dominant component of the intra seasonal variability in the tropical atmosphere. MJO typically characterized by eastward-traveling circulation cells moving along the equatorial plane, observed mainly over the Indian Ocean and the western Pacific Ocean (Eguchi et al., 2015). The dry MJO phase with dry February is quite high, but there are several years of the dry MJO phase which experience normal rainfall. Moreover, the percentage of dry phase days in 2014 is not an extreme value. Thus, we argue that while playing a major role, the MJO event is not a major contributing factor to the very low rainfall event (McBride et al., 2015).

\section{$2^{\text {nd }}$ Drought of Riau}

The $2^{\text {nd }}$ drought season in Riau was caused by monsoonal season event. This drought season happened in June until late August. In this period, the phenomenon of ENSO and IOD also began to occur, so the analysis in this drought season was carried out from May until October. Compared to the first one, the $2^{\text {nd }}$ drought season in Riau also has a similar duration. Figure 5 shows that almost every year have a similar number of hotspots with less than 2,000 hotspots in a month. In the 2019 event, the number of hotspots was affected by strong positive IOD that happened. Although the number of hotspots in August 2019 was more than 2,000 hotspots in a month, the number of
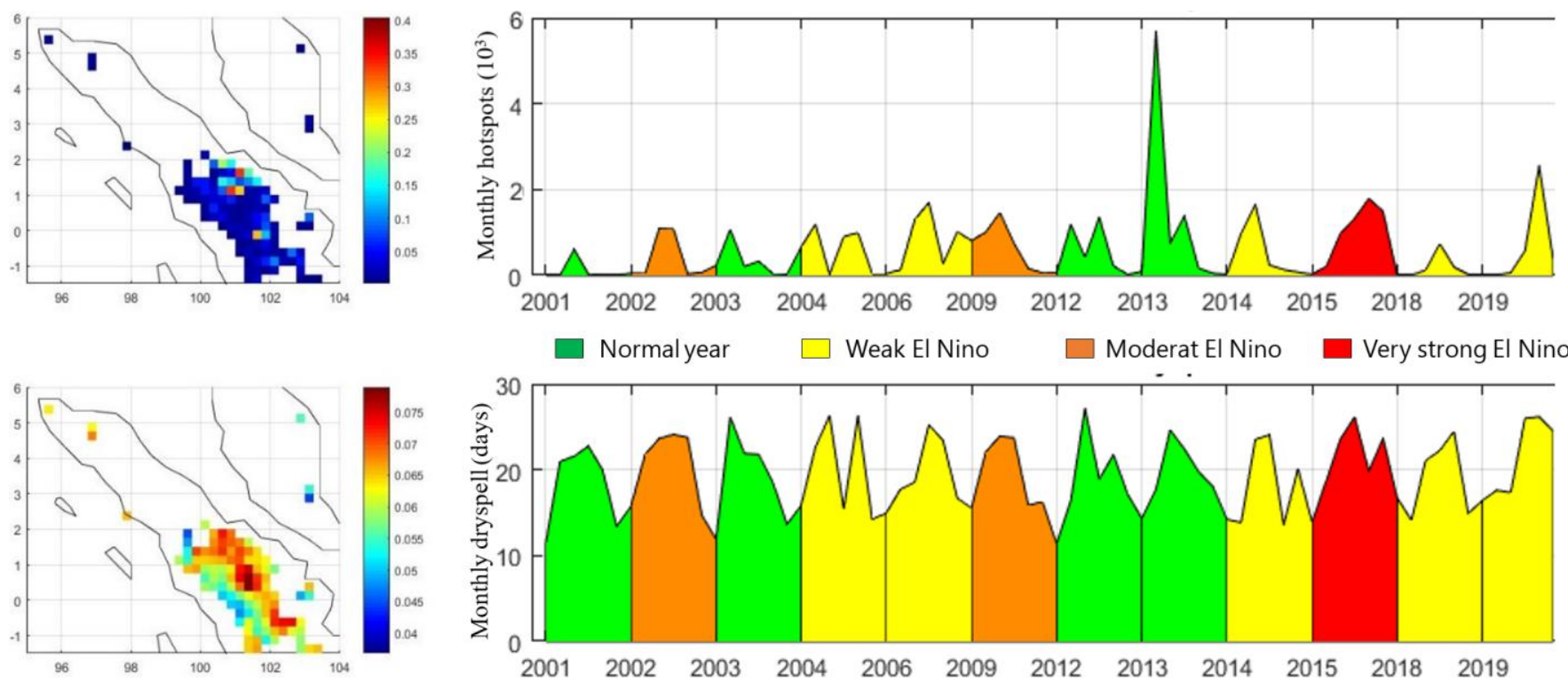

Figure 5. Spatial distribution of severity level and temporal pattern of hotspots (top) and spatial distribution of severity level and temporal pattern of dry-spell (bottom) in the second drought season in Riau during normal year. 
hotspots in October 2019 was drastically reduced by the monsoonal rainy season.

Figure 5 shows that in 2015, the number of hotspots was more than 1,000 hotspots in each month from July to October with the total number of hotspots was more than 5,000 hotspots. From this result, we suggest that very strong El Niño event has a slight impact on drought season and to the number of hotspots in the $2^{\text {nd }}$ drought season in Riau. Compared to the others, the impact was smaller in this region because of monsoonal rainy season that arrived during late October to early November.

The highest number of hotspots in $2^{\text {nd }}$ drought season in Riau happened in 2013 with almost 6,000 hotspots in June 2013. The number of hotspots peaked in June when the lowest rainfall observed during the year was equal to $56.08 \mathrm{~mm}$. The amount of rainfall was far below normal (of 30 years average) which is 145.06 $\mathrm{mm}$. On April and May (the period before the peak fire), a deficit of rainfall also arrived which allowing the accumulation of dry-spell and causing a large number of hotspots occurred in June (Kusumaningtyas and Aldrian, 2016).

Figure 6 shows the comparison of every fire season event in all regions during the years that had been analyzed before. Figure 6 shows that El Niño event influenced the lengthen of drought season in
Kalimantan and South Sumatra. This can be identified by examining the right side of the circle/box representing each fire event as the El Niño index increases. Also, positive IOD (IOD index > 0.4) contributed the same impact on both regions. This can be identified by examining the event that happened in the same categories of El Niño, the positive IOD event was on the right side of the normal IOD event. The positive IOD has a bigger impact on prolonging the length of drought season in South Sumatra and can be identified by examining the square with almost 110 dry-spells. Kalimantan and South Sumatra have a similar number of dry-spells which is $65-110$ days in 1 drought season.

Different from Kalimantan and South Sumatra, both El Niño and IOD didn't have a quite clear impact on the length of drought season in both drought season of Riau. It can be identified by examining the number of dry-spells that always around 45-70 days for all categories of El Niño and IOD. The anomalies in $1^{\text {st }}$ drought in Riau only appeared that indicates the 2014 event with 83 days of dry-spells. In the $2^{\text {nd }}$ drought season, hotspot anomalies occurred in June 2013 and 2015 with the number of dry-spells respectively 57 and 69 days. Even though the number of hotspots is higher than the other event, the number of dry-spells is quite similar in $2^{\text {nd }}$ drought season of Riau.

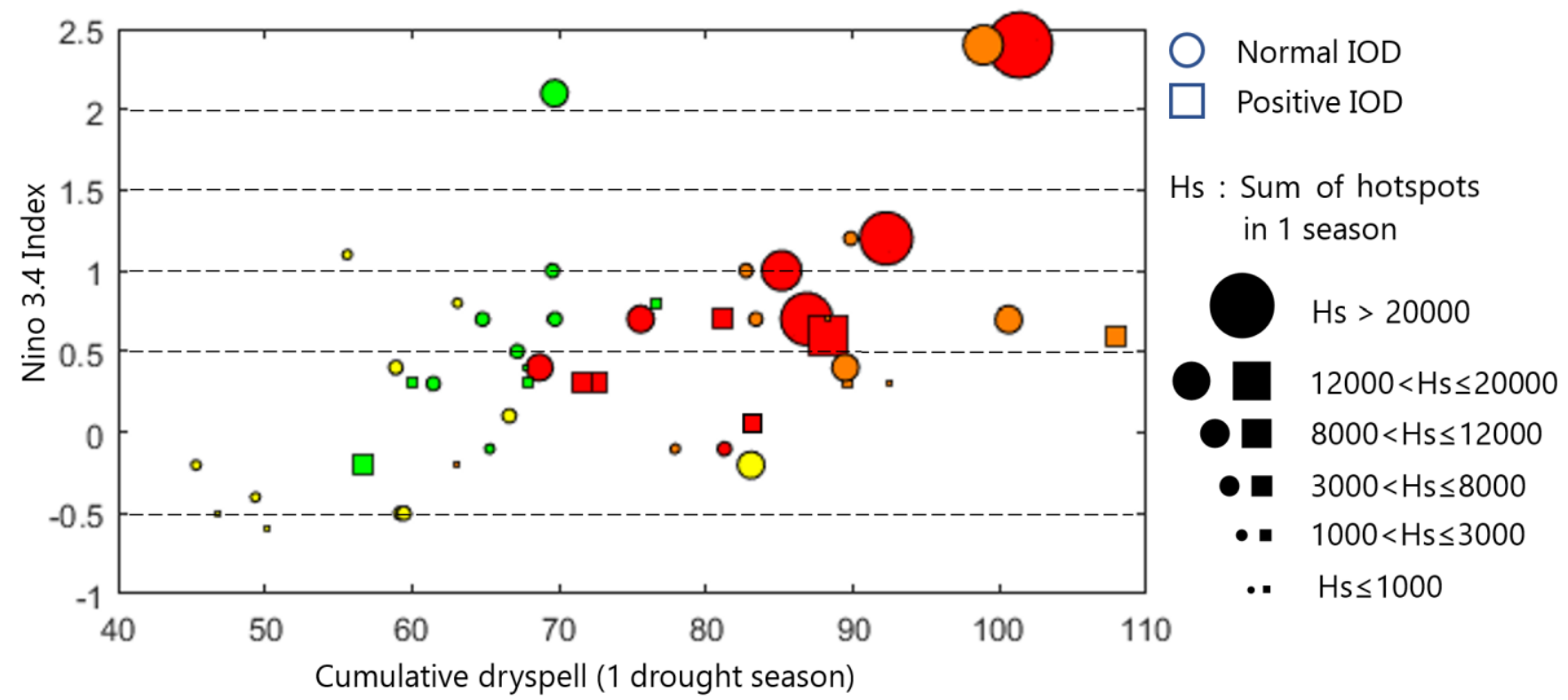

Figure 6. Summary of events for each fire season in all regions and years analyzed.

\section{CONCLUSIONS}

In general, El Niño affects the phenomenon of forest fires in Indonesia. However, the impact of El Niño differs for each fire-prone regimes in Indonesia, namely: Kalimantan, South Sumatra, and Riau. The greatest impact occurred in the Kalimantan region. The duration and number of hotspots in the Kalimantan region will be high when a moderate (or stronger) El
Niño phenomenon occurs. This is different from the South Sumatra region where the number of hotspots only increases rapidly when very strong El Niño occurred. So, we can conclude that Kalimantan was more sensitive for the El Niño phenomenon than South Sumatra. As a result, the government needs to increase preparedness in dealing with moderate (stronger) $\mathrm{El}$ Niño or weak El Niño that occurs together with the 
positive IOD phenomenon to anticipate a high number of hotspots in Kalimantan.

The results of this research in the Riau region indicate that the magnitude of the number of hotspots in the Riau region is not influenced by the El Niño phenomenon. This is also supported by the fact that the number of hotspots does not experience an increase in moderate and strong El Niño years. Therefore, to be able to find out the causes of forest fires in the Riau region, it is necessary to conduct research that is more focused on the phenomenon of fires that occur every year in the Riau region.

\section{ACKNOWLEDGEMENTS}

The authors would like to thank The Department of Mathematics, IPB University and The Meteorological, Climatological and Geophysical Agency for their strong support and invaluable assistance throughout this research.

\section{REFERENCES}

Albar, I., Jaya, I.N.S., Saharjo, B.H., Kuncahyo, B., 2016. Spatio-temporal typology of land and forest fire in Sumatra. Indonesian Journal of Electrical Engineering and Computer Science 4, 83-90. https://doi.org/10.11591/ijeecs.v4.i1.pp83-90

Albar, I., Jaya, I.N.S., Saharjo, B.H., Kuncahyo, B., Vadrevu, K.P., 2018. Spatio-Temporal Analysis of Land and Forest Fires in Indonesia Using MODIS Active Fire Dataset, in: Vadrevu, K.P., Ohara, T., Justice, C. (Eds.), Land-Atmospheric Research Applications in South and Southeast Asia. Springer International Publishing, Cham, pp. 105-127. https://doi.org/10.1007/978-3-31967474-2_6

Ardiansyah, M., Boer, R., Situmorang, A.P., 2017. Typology of land and forest fire in South Sumatra, Indonesia Based on Assessment of MODIS Data. IOP Conference Series: Earth and Environmental Science 54, 012058. https://doi.org/10.1088/17551315/54/1/012058

Arora, K., Dash, P., 2019. The Indian Ocean Dipole: A Missing Link between El Niño Modokiand Tropical Cyclone Intensity in the North Indian Ocean. Climate 7. https://doi.org/10.3390/cli7030038

Avia, L., Sofiati, I., 2018. Analysis of El Niño and IOD Phenomenon 2015/2016 and Their Impact on Rainfall Variability in Indonesia. IOP Conf. Ser.: Earth Environ. Sci. 166, 012034. https://doi.org/10.1088/17551315/166/1/012034
Björnsson, H., Venegas, S., 1997. A Manual for EOF and SVD Analyses of Climate Data. Department of Atmospheric and Oceanic Sciences and Centre for Climate and Global Change Research. McGill University, Technical Report.

Cai, W., Wang, G., Dewitte, B., Wu, L., Santoso, A., Takahashi, K., Yang, Y., Carréric, A., McPhaden, M.J., 2018. Increased variability of eastern Pacific El Niño under greenhouse warming. Nature 564, 201-206. https://doi.org/10.1038/s41586-018-0776-9

Capotondi, A., Deser, C., Phillips, A.S., Okumura, Y., Larson, S.M., 2020. ENSO and Pacific Decadal Variability in the Community Earth System Model Version 2. Journal of Advances in Modeling Earth Systems 12, e2019MS002022. https://doi.org/10.1029/2019MS002022

Chapman, S., Syktus, J., Trancoso, R., Salazar, A., Thatcher, M., Watson, J.E., Meijaard, E., Sheil, D., Dargusch, P., McAlpine, C.A., 2020. Compounding impact of deforestation on Borneo's climate during El Niño events. Environmental Research Letters 15, 084006. https://doi.org/10.1088/1748-9326/ab86f5

Demissie, S., Mengisitie, B., 2017. The impact of El Niño on diarrheal disease incidence: a systematic review. Science 5, 446-451. https://doi.org/10.11648/j.sjph.20170506.16

Doi, T., Behera, S.K., Yamagata, T., 2020. Predictability of the super IOD event in 2019 and its link with $\mathrm{El}$ Niño Modoki. Geophysical Research Letters 47, e2019GL086713.

https://doi.org/10.1029/2019GL086713

Eguchi, N., Kodera, K., Nasuno, T., 2015. A global nonhydrostatic model study of a downward coupling through the tropical tropopause layer during a stratospheric sudden warming. Atmos. Chem. Phys. 15, 297-304. https://doi.org/10.5194/acp-15-297-2015

Fanin, T., Werf, G.R.V.D., 2017. Precipitation-fire linkages in Indonesia (1997-2015). Biogeosciences 14, 3995-4008. https://doi.org/10.5194/bg-14-3995-2017

Hidayat, R., Juniarti, M., Ma'rufah, U., 2018. Impact of La Niña and La Niña Modoki on Indonesia rainfall variability. E\&ES 149, 012046. https://doi.org/10.1088/17551315/149/1/012046

Hidayati, R., Chrisendo, D.N., 2010. Prediction of Planting Date and Growing Period using Sea Surface Temperature (SST) Anomalies in Nino 3.4 for Indramayu District. Agromet 24, 1-8. https://doi.org/10.29244/j.agromet.24.2.1-8 
KLHK, 2020. Rekapitulasi Luas Kebakaran Hutan dan Lahan $(\mathrm{Ha})$ Per Provinsi Di Indonesia Tahun 2015-2020. Direktorat Pengendalian Kebakaran Hutan dan Lahan, Kementerian Lingkungan Hidup dan Kehutanan.

Kusumaningtyas, S.D.A., Aldrian, E., 2016. Impact of the June 2013 Riau province Sumatera smoke haze event on regional air pollution. Environmental Research Letters 11, 075007. https://doi.org/10.1088/17489326/11/7/075007

Lu, J., Jia, L., Menenti, M., Yan, Y., Zheng, C., Zhou, J., 2018. Performance of the Standardized Precipitation Index Based on the TMPA and CMORPH Precipitation Products for Drought Monitoring in China. IEEE Journal of Selected Topics in Applied Earth Observations and Remote Sensing 11, 1387-1396. https://doi.org/10.1109/JSTARS.2018.2810163

Ma, W., Feng, Z., Cheng, Z., Chen, S., Wang, F., 2020. Identifying Forest Fire Driving Factors and Related Impacts in China Using Random Forest Algorithm. Forests 11, 507. https://doi.org/10.3390/f11050507

McBride, J.L., Sahany, S., Hassim, M.E., Nguyen, C.M., Lim, S.-Y., Rahmat, R., Cheong, W.-K., 2015. The 2014 record dry spell at Singapore: an intertropical convergence zone (itcz) drought. Bulletin of the American Meteorological Society 96, S126-S130.

Mulyaqin, T., 2020. The Impact of El Niño and La Nina on Fluctuation of Rice Production in Banten Province. Agromet 34, 34-41. https://doi.org/10.29244/j.agromet.34.1.34-41

Nóia Júnior, R. de S., Sentelhas, P.C., 2019. Soybeanmaize off-season double crop system in Brazil as affected by El Niño Southern Oscillation phases. Agricultural Systems 173, 254-267. https://doi.org/10.1016/j.agsy.2019.03.012

Nur'utami, M.N., Hidayat, R., 2016. Influences of IOD and ENSO to Indonesian Rainfall Variability: Role of Atmosphere-ocean Interaction in the Indo-pacific Sector. Procedia Environmental Sciences 33, 196-203. https://doi.org/10.1016/j.proenv.2016.03.070

Qalbi, H.B., Faqih, A., Hidayat, R., 2017. Future rainfall variability in Indonesia under different ENSO and IOD composites based on decadal predictions of CMIP5 datasets 54, 012043. https://doi.org/10.1088/17551315/54/1/012043

Ruiz, S., Putraditama, A., 2019. Will the Start of Forest Fires Season Hamper Indonesia's Progress in Reducing Deforestation? World Resources
Institute.

URL https://www.wri.org/blog/2019/07/will-startforest-fires-season-hamper-indonesia-sprogress-reducing-deforestation

Septiawan, P., Nurdiati, S., Sopaheluwakan, A., 2019. Numerical Analysis using Empirical Orthogonal Function Based on Multivariate Singular Value Decomposition on Indonesian Forest Fire Signal. IOP Conf. Ser.: Earth Environ. Sci. 303, $012053 . \quad$ https://doi.org/10.1088/17551315/303/1/012053

Stiegler, C., Meijide, A., Fan, Y., Ashween Ali, A., June, T., Knohl, A., 2019. El Niño-Southern Oscillation (ENSO) event reduces $\mathrm{CO} 2$ uptake of an Indonesian oil palm plantation. Biogeosciences 16, 2873-2890. https://doi.org/10.5194/bg-162873-2019

Sun, Q., Wang, Y., Sun, Z., 2018. Rapid surface defect detection based on singular value decomposition using steel strips as an example. $\begin{array}{lll}\text { AIP } \quad \text { Advances } & 855209 .\end{array}$ https://doi.org/10.1063/1.5017589

Sun, S., Wang, Y., Liu, J., Cai, H., Wu, P., Geng, Q., Xu, L., 2016. Sustainability assessment of regional water resources under the DPSIR framework. Journal of Hydrology 532, 140-148. https://doi.org/10.1016/j.jhydrol.2015.11.028

Supari, Tangang, F., Salimun, E., Aldrian, E., Sopaheluwakan, A., Juneng, L., 2018. ENSO modulation of seasonal rainfall and extremes in Indonesia. Climate Dynamics 51, 2559-2580. https://doi.org/10.1007/s00382-017-4028-8

Surmaini, E., Susanti, E., Sarvina, Y., Syahputra, M.R., 2018. Development of Early Detection Method for Drought and Flood on Rice Paddy. Agromet 32,

81-92. https://doi.org/10.29244/j.agromet.32.2.81-92

Sze, J.S., Lee, J.S.H., 2019. Evaluating the social and environmental factors behind the 2015 extreme fire event in Sumatra, Indonesia. Environmental Research Letters 14, 015001. https://doi.org/10.1088/1748-9326/aaee1d

Taufik, M., 2010. Behavior Analysis of Drought Index in Fire-Prone Region of South Sumatra. Jurnal Agromet Indonesia 24, 9-17. https://doi.org/10.29244/j.agromet.24.2.9-17

Wahab, Moh.I., Sudibyakto, S., Gunadi, S., Suratman, W.S., 2009. Change in Spatial and Temporal Characteristics of Rainfall in East Java Province in Relation to Global Climate Change. Agromet 23, $29-44$. https://doi.org/10.29244/j.agromet.23.1.29-44

Yananto, A., Dewi, S., 2016. Analisis Kejadian El Nino Tahun 2015 dan Pengaruhnya Terhadap 
Nurdiati et al./Agromet 35 (1): 1-10, 2021

Peningkatan Titik Api di Wilayah Sumatera dan Kalimantan. Jurnal Sains \& Teknologi Modifikasi Cuaca 17, 11-19. https://doi.org/10.29122/jstmc.v17i1.544

Yulianti, N., 2013. The influence of precipitation patterns on recent peatland fires in Indonesia (Dissertation). Hokkaido University, Japan.
Zhang, L., Liu, Y., Zhao, F., 2018. Singular value decomposition analysis of spatial relationships between monthly weather and air pollution index in China. Stochastic Environmental Research and Risk Assessment 32, 733-748. https://doi.org/10.1007/s00477-017-1491-z 